УДК: $378.016: 821(100)+81 ’ 23+81^{\prime} 42$

DOI:

Інна Хижняк, доктор педагогічних наук, доиент, декан факультету початкової, технологічної та професійної освіти ДВНЗ “Донбаський державний педагогічний університет” Назар Ляшов, кандидат філологічних наук, доцент кафедри украӥнської мови та літератури ДВНЗ “Донбаський державний педагогічний університет”

\title{
ПСИХОЛІНГВІСТИЧНІ УМОВИ СПРИЙМАННЯ Й РОЗУМІННЯ СТУДЕНТАМИ- ФІЛОЛОГАМИ ТЕКСТУ ХУДОЖНЬОГО ТВОРУ
}

У статті показано багатоплановість поняття “текст", звернено увагу на психолінгвістичну специфіку дослідження тексту, проведено паралелі із методикою навчання літератури, яка потребує ефективного сприймання та розуміння тексту художнього твору. Автори обгрунтували важсливість дотримання таких психолінгвістичних умов сприймання й розуміння художнього тексту під час фахової підготовки майбутніх учителів-філологів: урахування психолінгвістичних класифікацій текстів під час укладання навчальноі програми з літератури; застосування системи завдань на конструктивне та продуктивне відтворення студентами змісту художнього тексту; системне використання перекладу фрагментів виучуваного художнього тексту зарубіжної літератури.

Ключові слова: текст; художній твір; психолінгвістичні умови; студенти-філологи; зарубіжна література.

Табл. 1. Лім. 10.

Inna Khyzhnyak, Doctor of Sciences (Pedagogy), Associate Professor, Dean of the Faculty of Primary, Technological and Vocational Education SHEE "Donbas State Pedagogical University" Nazar Lyashov, Ph. D. (Philology), Associate Professor of the Ukrainian Language and Literature Department SHEE "Donbas State Pedagogical University"

\section{PSYCHOLINGUISTIC CONDITIONS OF PERCEPTION AND COMPREHENSION BY STUDENTS-PHILOLOGISTS THE TEXT OF THE FICTION WORK}

In the article it is declared that the questions of the text's creation and semantic perception, comprehension and forming of its projections in a mind of a recipient, interaction between a reader and a text are important for a psycholinguistics problem field. These problems are also significant for the methods of teaching literature because one of the leading issues is a qualitative fiction works text's perception and comprehension. Methods of teaching foreign literature in higher education establishments should rely on the results of psycholinguistic research not only for improving the quality of future teachers professional literary training, but also for the students' assimilation and using the effective mechanisms of a fiction text's perception and comprehension in the whole complex of these processes psycholinguistic features in their own pedagogical practice.

Along with this, textbooks and manuals on Modern Ukrainian Literature, World Literature, History of Foreign Literature, etc. for higher education institutions take in account a few of psycholinguistic principles of the fiction works' text comprehension. This fact underlines relevance of the issue and lack of its investigations in modern psychological and pedagogical scientific literature. In connection with this the authors' aim in the article was argumentation of importance of adhering to the psycholinguistic conditions of fiction works' perception and comprehension in the students-philologists' studying process and illustrating the ways of its implementation during learning history of foreign literature.

As a result, in the article the authors distinguished the following psycholinguistic conditions of the fiction works' perception and comprehension by future philology teachers: during the designing of the literature curriculum it is expedient to alternate texts with different psycholinguistic features, complementing and strengthening its influence on the students' emotional and mental sphere; practical classes and independent work on literature should use a system of various tasks for the constructive and productive reproduction by students the fiction texts' content; it is worth to apply the translation of fragments of the learned fiction texts of foreign literature systematically and comprehensively.

Keywords: a text; fiction work; psycholinguistic conditions; students-philologists; foreign literature.

П

остановка проблеми у загальному вигляді та її зв'язок із важливими снауковими чи практичними

завданнями. У сучасній науковій думці поняття тексту виступає як категорія лінгвістична, літературознавча, психолінгвістична, педагогічна, 
мистецька і т.д. Значним є доробок іноземних та вітчизняних учених щодо визначення категорії тексту як одного із компонентів художнього твору, ознак текстуальності, аналізу тексту й дискурсу, особливостей структури й суб'єктів мовленнєвого акту тощо. Для проблемного поля психолінгвістики вагомими $є$ питання породження та смислового сприйняття тексту, взаємодії читача й тексту, розуміння тексту та утворення його проекцій в свідомості реципієнта (Н. Акімова, В. Бєлянін, Л. Виготський, Л. Воробйова, I. Гальперін, I. Горєлов, О. Горошко, Н. Дячук, С. Засєкін, Л. Калмикова, Г. Костюк, С. Куранова, О. Леонтьєв, К. Мізін, К. Сєдов, Н. Чепелєва та ін).

Подібні виклики постають і перед методикою навчання літератури, де одним із провідних питань $\epsilon$ якісне сприйняття та розуміння художнього тексту. Отже, методика навчання зарубіжної літератури у закладах вищої освіти має враховувати результати психолінгвістичних досліджень не лише для підвищення якості фахової літературознавчої підготовки майбутніх учителів, але й для засвоєння та подальшого використання ними у власній педагогічній практиці ефективних механізмів сприймання й розуміння тексту художнього твору в усьому комплексі психолінгвістичних ознак цих процесів.

Аналіз основних досліджень і публікацій. Зміст поняття “текст” повсякчас розглядають науковці різних галузей науки: М. Бахтін, Н. Валгіна, С. Васильєв, Г. Гадамер, І. Гальперін, М. Жинкін, А. Загнітко, І. Ковалик, І. Кочан, К. Леви-Строс, Ю. Лотман, Л. Мацько, В. Мельничайко, О. Мороховський, В. Одинцов, 3. Партико, Б. Потятиник, М. Плющ, В. Різун, О. Селіванова, Г. Солганик, Ф. де Соссюр, М. Феллер, М. Хайдеггер, В. Чернявська та ін.

Поняття тексту є настільки багатоплановим, що його не лише вивчають науковці, але й унаочнюють художники: картина К. Бухайстера “Композиція тексту”, на якій проступають темні і світлі смуги, розташовані горизонтально, діагонально та під кутом одна до одної, через що в глядача складається враження сітки, сплетіння, міцної внутрішньої структури $[10,14]$. Цей візуалізований приклад наочно висвітлює основні моменти, які є на сьогодні визначальними в наукових дискусіях: текст являє собою змістову єдність, структуроване та потенційно інтерпретоване ціле; текст складається з різноманітних елементів; текст існує всередині певного континуального (безперервного) явища як його фрагмент; межі тексту, його початок та кінець, відносні.

У вивченні художнього тексту повсякчас спостерігалася множинність підходів та спрямувань, які доповнювали один одного та сприяли більш повному розкриттю його природи в лінгвістичному аспекті. Однак із часом традиційне лінгвістичне вивчення тексту змістило дослідницький вектор від внутрішньої структури тексту до динамічних процесів психічного відображення. Вивчення художнього тексту почало розглядатися з антропоцентричних позицій за схемою: автор - текст - читач. У межах зазначеного підходу в залежності від вектору дослідження виділилося психолінгвістичне вивчення тексту, що складає його ядро (Л. Виготский, М. Жинкін, О. Леонтьєв, А. Лурія, А. Шахнарович та ін.). У психолінгвістиці текст художнього твору вивчається як цілісна одиниця, певний концепт, ментальне утворення [3; 4;9].

Характеризуючи цілісність як ознаку смислової єдності тексту або його відносно завершених уривків і як психолінгвістичну текстову категорію, що виражається в ієрархічній організації програм висловлювань, С. Куранова стверджує, що для читача зовнішні ознаки цілісності є сигналами, які дають змогу прогнозувати межі, обсяг, змістову структуру тексту, полегшуючи процес сприйняття. Дослідниця акцентує на тому, що для текстів, які функціонують у різних сферах інтелектуальної діяльності, існує набір ознак, зокрема: “науково - ненауково”, “популярно непопулярно”, “художньо - нехудожньо”, “цікаво - нецікаво”, “інформативно - неінформативно”. Поєднання таких ознак дає змогу орієнтувати текст на певну професійну групу і тим самим визначати його ефективне сприйняття і розуміння певною групою реципієнтів [4, 92].

Поряд із цим у підручниках і посібниках із сучасної української літератури, світової літератури, історії літератури тощо для 3ВО мало враховуються психолінгвістичні засади опанування художнього тексту. Дещо більше таких елементів можна спостерігати в підручниках і посібниках з методики навчання літератури для 3ВО [5], проте суто психолінгвістичним аспектам опрацювання художнього тексту в усій цілісності його текстуальних і позатекстуальних ознак і в них приділяється мало уваги. Усе це вказує на актуальність порушеної теми та недостатне висвітлення іï в сучасній психолого-педагогічній науковій літературі.

Формулювання мети статті (постановка завдання). Зважаючи на актуальність порушеної проблеми та недостатнє їі вивчення, метою статті $\epsilon$ обгрунтувати важливість дотримання психолінгвістичних умов сприймання й розуміння тексту художнього твору і показати приклади їх 
реалізації під час навчання майбутніх учителівсловесників історії зарубіжної літератури у ЗВО.

Виклад основного матеріалу дослідження. Психолінгвістичне вивчення тексту, що панує в сучасній науці, має закономірно відбиватися і на процесі сприймання та усвідомлення художнього тексту студентами-філологами. Задля цього ще на етапі укладання навчальної програми курсу літератури викладачу варто враховувати не лише літературознавчі, але й психолінгвістичні класифікації текстів. У цьому плані на особливу увагу заслуговує робота В. Бєляніна, де автор обгрунтував психолінгвістичну типологію художніх текстів за емоційно-смисловою домінантою. На основі відомостей про акцентуації свідомості автора й читача вчений виділив різні типи текстів за загальною мажорністю чи мінорністю їх тону: “світлі”, “темні”, “веселі”, “сумні”, “красиві” і под. Розробляючи цю типологію, В. Бєлянін [1] грунтувався на тому, що кожен мовний елемент, 3 яких складається текст, обумовлений не лише лінгвістичними, але і психологічними закономірностями: структуру будь-якого художнього тексту можна співвідносити з тим чи іншим типом акцентуації людської свідомості, причому в ролі центру тексту виступає його емоційно-смислова домінанта.

Іншою класифікацією, що, на наш погляд, вимагає уваги з боку викладача літератури, є психолінгвістична типологія текстів художніх творів італійського дослідника та письменника У. Еко, який зазначив, що існують тексти “закриті” (створені за готовими шаблонами мислення) та “відкриті” (передбачають максимальне читацьке домислення) [8].

Отже, першою психолінгвістичною умовою опрацювання художніх текстів зі студентамифілологами в освітньо-літературному процесі визначаємо таку: під час укладання навчальної програми із літератури доцільно чергувати тексти 3 різними психолінгвістичними ознаками, взаємодоповнюючи та посилюючи їх вплив на емоційно-почуттєву та ментальну сфери студента.

Наприклад, ураховуючи типологію текстів за емоційно-смисловою домінантою у власній практиці, намагаємося чергувати тексти мажорних і мінорних тонів (передусім у ліриці), а також прості і складні для усвідомлення студентами тексти, що посилює вплив кожної емоційної акцентуації на студентів. Особливу увагу до ліричних творів обумовлено тим, що “важливу роль у набутті теоретичних аналітиколітературних знань і методичних умінь і навичок належить ознайомленню з лірикою як родом та їі жанрово-тематичними групами" [7, 143]. Наприклад: мажорні А. Рембо “Відчуття", "Голосівки" - мінорні П. Верлен “Осіння пісня”, "Never more”, “Туга"; прості (творчість Г. де Мопассана) - складні (К. Гамсун "Пан”) та ін.

Текстів “закритого” типу в навчальних програмах, як і в самій літературі, - більшість, а “відкриті” тексти варто пропонувати студентам до розгляду й опанування рідше, щоб елементом незвичності сприймання посилити читацьке домислення тексту. Так, плануючи послідовність вивчення студентами-філологами художніх творів у програмі курсу “Історія зарубіжної літератури”, творчість Е. Золя, Г. де Мопассана, Дж. Лондона, Г. Джеймса, Т. Драйзера, О’Генрі відносимо до “закритих" текстів, а поезію французького символізму, творчість М. Метерлінка, Дж. Джойса, М. Пруста, Ф. Кафки, К. Гамсуна-до “відкритих”. Пропонуємо приклад тематики практичних занять для студентів-філологів, де чергуються "відкриті" та “закриті” тексти. Починаємо з лірики, щоб у повному обсязі розставити смислові акценти в новій текстуальній інформації.

Сприйняття художнього тексту - процес завжди осмислений, рефлексивний, але глибина його осмислення, рівень рефлексії можуть бути різними, залежачи від мотиваційної детермінації, від ієрархії установок, від надситуативної активності суб' єкта, від попереднього досвіду та його активізації у пам'яті, від духовно-моральних цінностей особистості [3; 4; 9]. Система духовноморальних цінностей студента-філолога $€$ важливим складником становлення його фахової компетентності і виступає об'єднувальною ланкою між культурою суспільства і внутрішнім світом особистості. Саме через це пріоритетним завдання сучасної вищої гуманітарної освіти С. Гуров слушно визначає навчання студентів посправжньому бачити, цінувати і зберігати вічні людські цінності як стратегічні орієнтири життя [2].

На одностайну думку психолінгвістів, розуміння художнього тексту значно поглиблюється під час перекладу його змісту в іншу форму шляхом своєрідної інтерпретації, оцінки, побудови власних ментальних процесів [3; 4; 9]. Відтак другою психолінгвістичною умовою опрацювання художнього тексту зі студентами-філологами $є$ застосування системи завдань на конструктивне та продуктивне відтворення змісту художнього тексту на практичних заняттях і в самостійній роботі.

Слід зазначити, що ця психолінгвістична умова опанування художнього тексту студентом традиційно є найбільш реалізованою в методиці 
Таблиця 1.

Приклад тематики практичних занять

із курсу "Історія зарубіжної літератури"

\begin{tabular}{|l|l|l|l|}
\hline 1 & Поезія французького символізму. Поль Верлен, Артюр Рембо. & відкритий \\
\hline 2 & “Жерміналь” Е. Золя - роман про пробудження народної свідомості. & закритий \\
\hline 3 & $\begin{array}{l}\text { Роман “Любий друг” Гі де Мопассана, як критика французького } \\
\text { суспільства. }\end{array}$ & закритий \\
\hline 4 & $\begin{array}{l}\text { Твір Ж. Верна “П’ятнадцятирічний капітан”, як прославлення сили } \\
\text { людського духу і розуму. }\end{array}$ & закритий \\
\hline 5 & $\begin{array}{l}\text { Нові засоби зображення внутрішнього світу людини у модерністській прозі. } \\
\text { Роман-епопея М. Пруста “В пошуках втраченого часу”. }\end{array}$ & відкритий \\
\hline 6 & Нові горізонти історичної прози. Роман Р. Л. Стівенсона “Чорна стріла”. & закритий \\
\hline 7 & Образ детектива у творах А. Конан-Дойля про Шерлока Холмса. & закритий \\
\hline 8 & Неоромантичні тенденції у ліриці Дж. Р. Кіплінга & закритий \\
\hline 9 & Втілення філософії естетизму в романі О. Вайльда “Портрет Доріана Грея”. & відкритий \\
\hline 10 & $\begin{array}{l}\text { Відображення в романі “Овід” Е. Л. Войнич атмосфери революційної Італії } \\
\text { ХІХ ст. }\end{array}$ & закритий \\
\hline 11 & Ідейно-художній аналіз драми Г. Гауптмана “Ткачі”. & закритий \\
\hline 12 & Специфіка втілення теми кохання в новелістиці С. Цвайга \\
\hline 13 & $\begin{array}{l}\text { Своєрідність авторського світобачення на світ реальності у новелі Ф. Кафки } \\
\text { “Перевтілення”. }\end{array}$ & відкритий \\
\hline 14 & Природа і людина у модерністському романі К. Гамсуна “Пан” \\
\hline
\end{tabular}

навчання літератури. У освітньому процесі практикуються різні види такого відтворення змісту тексту: тлумачення назви, укладання структурно-композиційних схем, складання плану, добір ключових слів (речень) до тексту, порівняння з іншими творами (за принципами подібності чи контрастності), переказ, реферат, анотація, придумування початку чи закінчення та ін. [5; 7]. Поряд із цим викладачі літератури у ЗВО не завжди вповні орієнтуються в психолінгвістичних коренях продуктивного опрацювання змісту художнього твору і недостатньо використовують потенціал цих завдань.

Наприклад, лише осмислена рематична домінанта в назві художнього твору допомагає студентам-філологам у сприйманні і розумінні його тексту: Стендаль "Червоне і чорне", Ж. Верн “Із Землі на Місяць”, Е. Хемінгуей “Старий і море”, М. Булгаков “Майстер і Маргарита”, Ф. Достоєвський “Злочин і кара”, Ф. Шиллер "Підступність і кохання", Мольєр “Міщанин - шляхтич”. Виділення ключових слів чи речень до творів значних обсягів $є$ важливими завданнями для усвідомлення загальної когезії та когерентності тексту.

Одним із важливих прийомів конструктивнопродуктивного опрацювання художнього тексту на заняттях із зарубіжної літератури є його переклад іншою мовою. С. Засєкін акцентував увагу на психолінгвістичному діяльнісному підході до перекладу художніх текстів з урахуванням праць класиків і сучасників перекладознавства, прикладного мовознавства і на їх основі подав психолінгвістичну модель художнього перекладу, де він кваліфікується як вид мовленнєвомисленнєвої діяльності перекладача, інтерпретатор постає як особистість, що підвищує ступінь вірогідності й об'єктивності в поясненні дослідником-перекладознавцем застосованих перекладацьких стратегій під час перекладу художнього твору [3].

Застосування перекладу на заняттях iз зарубіжної літератури на філологічному факультеті $\epsilon$ доцільним, адже почасту студенти-філологи вивчають одну чи дві іноземних мови. Відтак наступною вагомою психолінгвістичною умовою опрацювання художніх текстів зі студентамифілологами під час вивчення світової літератури $\epsilon$ переклад фрагментів виучуваного художнього тексту. Зауважимо, що дотримання цієї умови має певні особливості, бо практично переклад можна використати лише в тому разі, якщо оригінал тексту написано англійською (для певних спеціальностей - німецькою і французькою) мовами, тому в усіх можливих випадках застосування перекладу вважаємо його обов'язковим.

Так, перекладання фрагменту тексту із філософсько-алегоричної казки-притчі Антуана де Сент-Екзюпері “Маленький принц” можна організовувати як проектну роботу, як групову форму навчання на занятті, як елемент 


\section{ПСИХОЛІНГВІСТИЧНІ УМОВИСПРИЙМАННЯ ЙРОЗУМІННЯ СТУДЕНТАМИ-ФІЛОЛОГАМИ ТЕКСТУ ХУДОЖНЬОГО ТВОРУ}

індивідуальної роботи з обдарованими студентами тощо. На занятті можна запропонувати студентам-філологам невеликий фрагмент тексту українською для перекладу французькою:

Він зашарівся, потім озвався знову:

- Якщчо ти любиш квітку, щзо є одна-єдина на світі і тільки на одній з мільйонів і мільйонів зірок, изього досить: дивишся на зорі $i$ почуваєш себе щасливим. I кажеш собі: “Десь там - моя квітка..." Але коли баранець ї з'їть, то ие все одно, як коли б раптово погасли всі зорі. I ие, виходить, не має значення? [6].

Після 5 - 7 хвилин, відведених на переклад, показуємо зразок оригінального тексту французькою:

Il rougit, puis reprit:

- Si quelqu'un aime une fleur qui n'existe qu'à un exemplaire dans les millions et les millions d'étoiles, ça suffit pour qu'il soit heureux quand il les regarde. Il se dit: "Ma fleur est là quelque part...". Mais si le mouton mange la fleur, c'est pour lui comme si, brusquement, toutes les étoiles s'éteignaient! Et ce n'est pas important ça! [6].

Надалі варто обговорити зі студентами особливості передавання смислу абзацу різними мовними засобами в українській та французькій мовах, проаналізувати різні варіанти перекладів у різних студентів, обрати найбільш вдалий та близький до оригіналу варіант перекладу за смислом та емоційним навантаженням, інтенційними характеристиками твору тощо.

Висновки 3 дослідження і перспективи подальших розвідок у цьому напрямі. У результаті аналізу психолого-педагогічної літератури було виокремлено основні психолінгвістичні умови, дотримання яких на заняттях із зарубіжної літератури є необхідним для якісного сприймання та розуміння студентами тексту художнього твору: під час укладання навчальної програми 3 літератури доцільно чергувати тексти із різними психолінгвістичними ознаками, взаємодоповнюючи та посилюючи їх вплив на емоційно-почуттєву та ментальну сфери студента; на практичних заняттях та в самостійній роботі 3 літератури слід використовувати систему різнопланових завдань на конструктивне та продуктивне відтворення студентами змісту художнього тексту; варто системно й комплексно застосовувати переклад фрагментів виучуваного художнього тексту зарубіжної літератури.

Проведений теоретико-практичний аналіз проблеми визначення й урахування психолінгвістичних умов опрацювання художнього тексту зі студентами-філологами на заняттях із зарубіжної літератури засвідчив актуальність і багатоаспектність цього питання, потребу в подальшому розвитку в напрямі розширення кола психолінгвістичних умов, більш докладного дослідження реалізації кожної із них на практиці, перевірціїх ефективності, апробації на науковому рівні.

\section{ЛIТЕРАТУРА}

1. Белянин В. П. Основы психолингвистической диагностики: модели мира в литературе. Москва, 2000. $123 \mathrm{c}$.

2. Гуров С. Сутність духовно-моральних цінностей особистості у філософсько-педагогічному дискурсі. Молодь і ринок. Щомісячний науково-педагогічний журнал. Дрогобич. 2018. № 6(161). C. 85 - 89. DOI: https:/ /doi.org/10.24919/2308-4634.2018.136874

3. Засєкін С. В. Психолінгвістичні універсалії перекладу художнього тексту : монографія. Луцьк, 2012. $272 \mathrm{c}$.

4. Куранова С. І. Основи психолінгвістики : навч. посіб. Київ, 2012. 208 с

5. Пасічник Є. А. Методика викладання української літератури в середніх навчальних закладах : навч. посіб. Київ, 2000.384 с.

6. Сент-Екзюпері А. Маленький принц. SaintExupéry A. Le Petit Prince. Серія : Паралельний текст / перекл. П. Таращук. Харків, 2015. 160 с.

7. Сиротенко В., Бондаренко О. Особливості проведення практичних занять при вивченні інтеграційного курсу “Дитяча література з методикою навчання літературного читання”. Професіоналізм педагога: теоретичні й методичні аспекти. Електронне фахове видання. Слов'янськ. 2018. № 7. C. 137 - 149. DOI: https://doi.org/10.31865/24149292.7.2018.140591.

8. Умберто Э. Роль читателя. Исследования по семиотике текста / Перев. с англ. и итал. С. Д. Серебряного. Санкт-Петербург, 2005. 502 с.

9. Чепелєва Н.В. Текст і читач : посіб. Житомир, 2015. $124 \mathrm{c}$.

10. Чернявская В. Е. Лингвистика текста: Поликодовость, интертекстуальность, интердискурсивность: учебн. пособ. Москва, 2009. 248 с.

\section{REFERENCES}

1. Belianin, V.P. (2000). Osnovy psikholingvisticheskoi diagnostiki: modeli mira v literature [Fundamentals of psycholinguistic diagnostics: models of the world in literature]. Moscow, 123 p. [in Russian].

2. Gurov, S. (2018). Sutnist duhovno-moralnih tsinnostey osobistosti u fllosofsko-pedagogichnomu diskursi [Essence of spiritual and moral values of personality in philosophical and pedagogical discourse]. "Youth and market". Monthly scientific-pedagogical journal. Drogobych, Vol. 6(161).pp. 85-89. DOI: https:// doi.org/10.24919/2308-4634.2018.136874 [in Ukrainian].

3. Zasiekin, S. V. (2012). Psykholinhvistychni universalii perekladu khudozhnoho tekstu [Psycholinguistic universals of translating fiction texts]. Lutsk, 272 p. [in Ukrainian]. 
4. Kuranova, S. I. (2012) Osnovi psikholingvistiki [Fundamentals of psycholinguistics]. Kyiv, 208 p. [in Ukrainian].

5. Pasichnyk, Ye. A. (2000). Metodyka vykladannia ukrainskoi literatury $v$ serednikh navchalnykh zakladakh [Methods of Teaching Ukrainian Literature at Secondary Educational Establishments]. Kyiv, 384 p. [in Ukrainian].

6. Sent-Ekziuperi, A. (2015). Malenkyi prynts. Le Petit Prince [The Little Prince]. Kharkiv, 160 p. [in France].

7. Sirotenko, V. \& Bondarenko, O. (2018) Osoblivosti provedennya praktichnih zanyat pri vivchenni integratsiynogo kursu "Dityacha literatura z metodikoyu navchannya 1Iteraturnogo chitannya" [Features of Practical Classes in Studying the Integration Course
"Children's Literature with the Methods of Literary Reading"]. "Profesionalizm pedagoga: teoretichni $i$ metodichni aspekti". Electronic scientific journal. Sloviansk. Vol. 7. pp. 137 - 149. DOI https://doi.org/ 10.31865/2414-9292.7.2018.140591. [in Ukrainian].

8. Umberto, E. (2005). Rol chitatelia. Issledovaniia po semiotike teksta [The Role of the Reader: Explorations in the Semiotics of Texts]. Saint-Petersburg, 502 p. [in Russian].

9. Chepeleva, N.V. (2015). Tekst i chitach [Text and reader]. Zhitomir, 124 p. [in Ukrainian].

10. Chernyavskaya, V. Ye. (2009). Lingvistika teksta: Polikodovost, intertekstualnost, interdiskursivnost [Text Linguistics: Polycodedness, intertextuality, interdiscursiveness]. Moscov, 248 p. [in Russian].

Стаття надійшла до редакції 22.07.2019

УДК 371.132: 316.422

DOI:

Володимир Ковальчук, доктор педагогічних наук, професор, завідувач кафедри математики, інформатики та методики їх викладання у початковій школі Дрогобицького державного педагогічного університету імені Івана Франка

\section{МОДЕРНІЗАЦІЯ СУЧАСНОЇ ПЕДАГОГІЧНОЇ ОСВІТИ: СВІТОГЛЯДНІ АСПЕКТИ}

Автор статті розглядає актуальні проблеми модернізачії вітчизняної педагогічної освіти; визначає основні напрями подолання кризових явищ в освіті, необхідність семантичних та аксіологічних трансформацій у свідомості сучасного спеціаліста і вчителя зокрема. У ряді випадків існуюча практика розвитку педагогічної освіти не відповідає вимогам сучасного інформаційного й техногенного суспільства, а тому не може забезпечити своєчасну й адекватну підготовку молодих людей до майбутнього. На думку автора, не менш важливим аспектом модернізації освіти виступає вплив ї̈ на розвиток демократичних засад у суспільному житті.

Ключові слова: модернізація; світогляд; освітня політика; соціалізація; культура.

Jim. 5.

Volodymyr Kovalchuk, Doctor of Sciences (Pedagogy), Professor, Head of the Mathematics, Informatics and Methods of Teaching them at Elementary School Department Drohobych Ivan Franko State Pedagogical University

\section{MODERNIZATION OF MODERN PEDAGOGICAL EDUCATION: WORLDWIDE ASPECTS}

The author considers the actual problems of modernization of the national pedagogical education; defines the main directions of overcoming crisis phenomena in education, the need for semantic and axiological transformations in the consciousness of modern specialist and teacher in particular. According to the author's opinion, a very important aspect of the modernization of education is its impact on the development of democratic principles in public life. In some cases, the current practice of developing pedagogical education does not meet the requirements of modern information and technogenic society, and therefore cannot provide timely and adequate preparation of young people for the future. Also, a number of contradictions, which are inherent to the problem of the modernization of pedagogical education in the conditions of the crisis of education, which has become planetary scale, has been carried out. Significant divergence of views on the existing and inevitable processes of transformation and modernization of pedagogical education is noted. The reasons and factors influencing the development of the present stage of development of the national pedagogical education, adjusting the existing definitions, are determined. The analysis of functional disorders of the education system is given, the causes of their emergence and ways of their overcoming are given, as well as the notion of pedagogical problem is defined.

Thus, the analysis carried out by the author testifies to the essential difference between the conditions of occurrence and the conditions of solving the problems of the pedagogical education in time-the first ones precede the second. The main factors contributing to overcome the pedagogical problem are also identified. It is also 